\title{
A performative framework for the study of intellectuals
}

\author{
Patrick Baert \\ University of Cambridge, Cambridge, UK \\ Marcus Morgan \\ University of Cambridge, Cambridge, UK
}

\begin{abstract}
This article introduces a new, performative framework for analysing intellectuals and intellectual interventions. It elaborates on the strengths of this theoretical perspective vis-à-vis rival approaches and develops this frame of reference by exploring key constituent concepts, including positioning, script and staging. The article then exemplifies the framework and demonstrates its applicability by exploring a public intellectual performance by Jean-Paul Sartre. To conclude, the article reflects on recent shifts in public intellectual performances, especially changes that are relatively durable and connected to the rise of new media.
\end{abstract}

\section{Keywords}

existentialism, performativity, positioning, social drama, social media, sociology of intellectuals

This article puts forward a performative framework for analysing intellectual interventions. We will explain the broad rationale behind this dramaturgical approach and show what its advantages are in relation to rival approaches. This will enable us to present the main outline of this theoretical perspective and introduce its core concepts. We will also explain the import of the framework for assisting in the analysis of mechanisms of reception, appreciation and rejection of intellectual products. We then provide a brief analysis of a public intellectual performance by Jean-Paul Sartre. Towards the end of the article, we will show how this theoretical outline can illuminate recent shifts in the nature

Corresponding author:

Patrick Baert, Sociology Department, University of Cambridge, Free School Lane, Cambridge CB2 3RQ, UK.

Email: pjnbI00@cam.ac.uk 
of public intellectual engagement, especially in Europe and North America. We focus in particular on two types of changes at the level of performativity: we note how intellectuals increasingly build a self-conscious awareness of performance into their performances themselves, and we comment on changes that are visibly connected to the arrival of new social media. It is our contention that these recent technological changes have substantially altered the public intellectual realm, though not always in a straightforward or linear fashion.

While the article takes as its starting point the relevance of positioning theory for the study of intellectuals (see also Baert, 2015: 158 -89), its focus will be on how this positioning theory can be enriched with the help of the dramaturgical approach. By the latter, we refer to a theoretical orientation that attempts to account for intellectual life through the notion of performance in two primary ways. First, in a weaker sense, we draw upon illuminating analogies with the stage and related metaphors; and, second, in the stronger sense, we acknowledge and examine the actual performance present within social action. For the sake of clarity, it is worth pointing out that we are using the term 'intellectual intervention' broadly, referring to any contribution (a talk, a book, an article, a blog or any section thereof) that is seen to be engaging with issues of ideational significance. By positioning theory, we refer to a theoretical approach that conceives of intellectual interventions as attributing features to their authors and to others - locating them within the intellectual and political field.

It will become clear throughout this article that the performative perspective that we propose is also eminently applicable to the study of the internal world of academia (e.g. Morgan and Baert, 2015) and some of our examples will be derived from that realm. We will, however, broaden our focus here to account also for interventions made by public intellectuals. By public intellectuals, we refer to intellectuals, who, while possibly drawing on their expertise in a specific area, address a broader public and engage with what are considered to be significant social and political issues of the day which go well beyond their narrow field of professional focus. We are conscious of the fact that the distinction between 'intellectual' and 'public intellectual' is not always clearcut and that at some level any intellectual activity implies an engagement with $a$ public (Collini, 2006). Indeed, etymologically speaking, the term 'intellectual' has connotations of publicness: it was initially coined to refer to supporters of Alfred Dreyfus, who drew upon their intellectual authority to speak out publicly in defence of the Jewish army officer against accusations of treason (Charles, 2015). Nevertheless, there is currency in holding on to the conceptual differentiation between 'intellectual' and 'public intellectual' , with 'public' referring to an engagement clearly beyond specialized circles and the academic realm. Without this distinction, it would be difficult to appreciate the uniqueness of intellectual interventions in the public realm, especially in relation to the role of new media.

With this performative framework, we intend to distance ourselves from two dominant assumptions that are shared by various theoretical and methodological perspectives in the sociology of intellectuals (and, to a certain extent, in intellectual history). The first assumption we wish to question is the idea that the sociological study of intellectuals should focus mainly, if not exclusively, on the structural factors that explain why certain ideas or interventions came into being. There are two main strands in this approach. 
Some sociologists focus on factors internal to the milieus in which intellectuals operate; take, for instance, Bourdieu' s exploration of the internal dynamics of elite academic institutions in France (e.g. Bourdieu, 1998). Others analyse structural conditions that are external to these milieus; traditionally Marxist-inspired approaches tried to show why the class affiliations of an intellectual (or, possibly more crudely, a particular mode of production in operation at the time) were linked to the ideas of different groups (e.g. Lefebvre, 1946; Gramsci, 1971 [1929 - 1935]). Whatever their differences, both strands share the presupposition that the primary task of the sociologist is to uncover the deeper structural dynamics at work that affect the shape of intellectual production. Both strands have proven to be productive research programmes, demonstrating that intellectual activities do not take place in a social vacuum, but their weakness lies in the way in which they tacitly or explicitly underplay intellectuals' agency. The intellectuals and their products tend to be portrayed as recipients of social forces and there is too little exploration of the myriad performative and strategic devices which intellectuals employ to get their message across. Further, in this type of work, insufficient attention is given to how and why certain intellectual products 'catch on' and others do not - how certain ideas are taken up, adopted and possibly altered in the process.

The second presupposition we wish to question concerns intentionality. Without wishing to engage directly in the ongoing theoretical debate, initiated by Mills (1940) over the place of motives in sociology, our performative perspective does challenge the methodological assumption that sociological research (or indeed intellectual history) is easily or automatically able to reconstruct the intentions or motives behind certain intellectual interventions. Sometimes a social analyst can, with justification, impute a motive behind social action; other times one cannot. To decide in which instance one can (or cannot) should always be on the basis of the empirical material available.

Relatedly, social research occasionally attempts to uncover a theme, principle or outlook that supposedly runs throughout the trajectory of the intellectual who is being discussed, arguably providing an in-depth explanation as to their specific intentions or motives on any occasion. This methodological perspective can often be found in biographies of major intellectual figures, and the reason for this might be relatively straightforward: being able to attribute intentions to writings or speeches brings to life and gives intuitive sense to what is otherwise at risk of becoming a dry narrative - simply a succession of facts. Relying upon the idea that a particular worldview or a relatively constant self-concept guides the intellectual provides coherence to any such biography. Neil Gross' s (2009) sociologically-inspired biography of the American philosopher Richard Rorty provides a good example of this approach. Gross argues that Rorty' s parental background accounts for his self-concept as a progressive pragmatist intellectual and that it was this theme of a left-leaning Deweyan that ran throughout Rorty' $\mathrm{s}$ intellectual trajectory. While there is no doubt that this methodological strategy has led to successful accounts of the intellectual trajectory of individual figures, these storylines, centred as they are around intentions and themes, tend to be beset by two problems. First, it is often difficult to find conclusive empirical evidence for making claims about the motives and intentions of individuals, and therefore the narratives presented within this methodological perspective tend to be speculative in nature. Second, this perspective sometimes overstates the coherence within an intellectual' s trajectory, overlooking the 
changes in positions that often occur, and the possible structural causes of these alterations, something Rorty (1989) himself in fact captured with his term 'contingency' . This issue is evident in Gross' s otherwise compelling biography: in spite of Rorty' s sympathies for Dewey' s pragmatism, he seemed to set those interests aside for more than two decades, operating comfortably within the contours of the analytic philosophy dominant at the time. Only when he had managed to obtain secure tenure and then a senior position did Rorty revisit his pragmatist roots and rebel against the reigning orthodoxy of the day. This case demonstrates the extent to which intellectuals regularly shift positions and sometimes do so in response to constraints and incentives.

\section{Theoretical outline}

Applied to intellectuals, the dramaturgical approach we are outlining accounts for their activities in two principal ways. First, in the tradition of theatrum mundi, it makes sense of intellectual activities by drawing on illuminating analogies and metaphors related to the theatre. Underlying this perspective is the contention that analogies are central to explaining social phenomena (Collins, 1976), and that similarities (and mutatis mutandis dissimilarities) with the stage are helpful in understanding certain distinctive features of intellectual life. Second, building upon a rich tradition in philosophy and the social sciences (e.g. Austin, 1957; Goffman, 1959; Turner, 1968, 1974; Schechner, 1977; Geertz, 1980; Butler, 1997; Alexander, 2004, 2016), we analyse social drama not only as analogous to performance, but in fact as performance proper itself. In other words, we argue that social performance frequently contains many, and sometimes all, of the characteristic hallmarks (actors, audiences, stages, rehearsal, symbolic communication, improvisation, direction, etc.) of more formalized modes of performance. We therefore understand stage or screen dramas as distinct from social dramas more in terms of degrees of control over formalization, framing, and focus - that is, in terms of differences in intensity rather than type.

While we find great inspiration from many of these other approaches to social performance, we find limitations in them too. In much of the anthropological literature, for instance, performance has been too strongly associated with bounded forms of ritual and ceremony. While ritual events no doubt bring performance to the fore, as indeed we acknowledge in what follows, such an approach has a tendency to divert analytical attention away from other, perhaps more banal, instances of performance, and so miss the ubiquity of the phenomenon. Micro-sociologists brilliantly opened up the centrality of performance in face-to-face interactions, providing an innovative view of the social as constructed from the impression management built up over countless self-presentations, but too often this account has rested upon psychological assumptions of instrumental intent, and without adequately linking the micro to the broader, shared and sociallystructured powers that enable or constrain those performances. Performance Studies theorists have advanced the field enormously by bringing to bear their expertise in stage drama, but have sometimes lacked a sense of the uniqueness of the social field in itself.

American cultural sociology has successfully addressed many of the limitations of these former approaches and, at least more recently, reinstated the importance of power that was perhaps lacking in their own earlier contributions. They have also applied their 
perspective to a huge variety of empirical settings, illustrating the methodological centrality of cultural performance. While we again draw much from this work and find cultural sociological schemas to be useful heuristics, ${ }^{1}$ we also find that they can become limiting once an assumption of a priori elements of performance is allowed to constrain a more promiscuous and unconstrained reading of the empirical free-flow of dramatic social action, and in particular the inextricable link between the cultural and material realms. As will become apparent near the end of this article, much of the new cultural sociological approach is also built on an inexplicit assumption of a particular traditional and generic genre of social performance which, at least in the intellectual realm, is showing some signs of breaking down.

Crucial to our own dramaturgical approach are the notions of performativity and positioning. Intellectual interventions can be seen as performative in that they bring something into being - they do something. One of the basic principles underlying this approach is that any intellectual intervention, even a purely scholarly one, has effects, however minute they may be. While focusing upon the symbolic representation inherent in performances has proven productive, it can also be fruitful to analyse intellectual interventions in terms of their observable consequences. In the case of public intellectuals, for instance, the overtly political nature of many interventions initiated by such intellectuals means that their effects upon the public realm can be empirically traced and reconstructed.

We regard the notion of positioning as a central feature of performativity. Positioning refers to the process by which individuals ascribe certain characteristics to themselves and to others. Indeed, we regard intellectual interventions as bringing about positioning: through their writings and speeches intellectuals wittingly or unwittingly attribute various features to the authors and to others (see also Baert, 2015). These characteristics are often put in terms of dichotomies such as 'left vs. right' , 'high-brow vs. low-brow' , 'white vs. black' , etc. (cf. Lévi-Strauss, 1969). Another way of putting this is to suggest that intellectual interventions always locate the authors within the specific cultural architecture of the time, while also situating others. Indeed, in accordance with structuralist insights, self-positioning (the attribution of features to oneself) is often made possible through the positioning of others, either by showing affinities with them or through juxtaposition (again, using dichotomies). It was, for instance, through contrast with social contract theorists that Durkheim was able to locate one of the central themes of his own sociological approach (Durkheim, 1997 [1893]), just as within the context of post-1945 Britain, Isaiah Berlin, Friedrich von Hayek, and Karl Popper positioned themselves within a liberal tradition through their critical readings of Marx and Marxism (Berlin, 1967; Popper, 1971 [1945a], 2002 [1957] 2013 [1945b]; Hayek, 2001 [1944]).

Actors engaging in positioning and self-positioning draw on various dramaturgical devices; they range from stage-setting and genre conformity to rhetorical moves in how arguments are presented. We will return to these dramaturgical devices below. It is important, at this stage, to emphasize that positioning is rarely an individual endeavour. First, as in other modes of social performance (Goffman, 1959), intellectuals often organize themselves into teams, since such team work is particularly effective for achieving the kinds of ends that positioning often tends towards. The Frankfurt School, the Bloomsbury group or the Tel Quel circle are examples of intellectual teams: their 
connections helping them to bring about collective positioning, while simultaneously allowing for individual differences. These three teams relied upon strong, intimate relationships and such strong bonds often make for effective networks (see also Collins, 2000), though many intellectual teams today operate without ongoing face-to-face interactions, let alone strong, affective ties. Second, intellectuals always form part of broader networks, which go well beyond the boundaries of their immediate team. These may well include opponents and critics and, in accordance with insights from social network analysis (Granovetter, 1973), these broader networks help them organize intellectual activity, as well as ultimately define who they are. However carefully intellectuals aim to locate themselves - and as we have mentioned, positing intentionality can on occasion be justified - the process of positioning is never entirely within their control, as other intellectuals will influence how their own positioning plays itself out.

This indeterminate element also means that, through time, someone' s positioning can shift substantially, even if he or she does not necessarily intend to bring this about. Posthumous repositioning is well documented: certain intellectuals and their inventions may suddenly be seen in a new light. They may also gradually be forgotten or rediscovered. There are many recent examples of this posthumous repositioning: take, for instance, Bruno Latour' s attempts at reviving Tarde and demoting Durkheim' s canonical position (Latour, 2001); progressive intellectuals such as Chantal Mouffe and Giorgio Agamben who 're-discovered' Carl Schmitt; or, in the aftermath of the economic crisis, previously laissez-faire economists, such as Richard Posner, who started to re-appreciate Keynes' s insights (Posner, 2009). Other examples include the reassessment of Paul De Man' s writings following the discovery of his anti-Semitic wartime journalism, the challenge mounted by Derek Freeman (1983) to Margaret Mead' s ethnographic work in Samoa, or the shift in reception of Malinowski' s work following his widow' s controversial decision to publish his diaries from New Guinea and the Trobriand Islands (Malinowski, 1967). This last example is a classic case of how repositioning can be provoked through the unanticipated exposure of an audience to the backstage (more of which below), after having previously only been granted access to the front stage of a performance. $^{2}$

Performativity and positioning imply an actor and an audience. The actor refers to any individual or group of individuals who is responsible for initiating the intellectual intervention, whereas the audience acts as the recipient. The actors normally have some idea of the nature of their audience, which enables them to put themselves in the perspective of the audience to ensure their message gets across. This is more likely to be the case when addressing small groups of carefully selected, and perhaps like-minded, individuals. In Ancient Greece, for instance, Plato was particularly concerned with choosing his audience to ensure that his message would not go astray (Booth, 2015). Beyond small circles, however, it is impossible to keep com- munication cut off from hermeneutic indeterminacy. Take the simple case of a lecture: as with theatre, actors will have some understanding of whom they are addressing, but they are unlikely to know every member of the audience. Also, the lecture might be recorded, which would add further uncertainty as to the extended audience. This relative indeter- minacy also applies to the printed text: although authors normally have a particular audience in mind, once the text has been published, they inevitably lose control over 
who reads it, the reasons people may have for reading it, and of course how the text will be understood. In general, while actors may have particular views as to what their intellectual interventions are meant to convey, these do not necessarily correspond to interpretations by the audience. Encoding and decoding do not always correspond. This has of course always been the case, but there are compelling reasons to believe that indeterminate interpretation has increased over time: not only have audiences multiplied in number and become progressively more heterogeneous, but the growth of new media has also been characterized by the proliferation of edited, cut-up, deracinated, decontextualized, and re-contextualized messages.

As we know, any theatrical performance is set upon a stage. As such, the stage both empowers and restricts the performance: it provides a setting against which the performance makes sense, but it also imposes a certain meaning on to it, closing off others. In a similar fashion, intellectual interventions take place within a particular setting which enables, constrains, and helps attribute meaning to them. Historically, major religions provided a 'sacred' platform for prophets or priests (Weber, 1920, 1978), but the advent of the Enlightenment weakened the link between religion and intellectualism, and, at least in the West, the staging of intellectual interventions have tended to become more secular. This formal secularism must not, however, be mistaken for the evacuation of the sacred from social performance. Literary salons emerged during this period, providing an impressive stage, not only for the exhibition of good manners and taste, but also for the transmission of intellectual ideas. The importance of the host, such as Isabella d' Este, the grandeur of the décor, and the high-society connections helped to provide legitimacy to such occasions and indeed sacralize the ensuing intellectual exchanges (Craveri, 2007). The creation of the bourgeois public sphere in the course of the nineteenth century weakened the centrality of patronage to the intellectual sphere, but it continued the further dissociation between the religious and the public intellectual realms (Sennett, 1977; Habermas, 1992). Up to the present day, the identity of the host nevertheless remains an important element in legitimizing or delegitimizing performances, whether it is in the form of an individual introducing a speech or acting as editor of a publication or, impersonally, in the form of an institution providing a venue or organizational link. With the rise of the mass media, specific outlets also present an effective stage, with famous talk shows like Apostrophes, hosted by Bernard Pivot on French television from the 1970s to the early 1990s, providing attractive opportunities for intellectuals to reach out to their prospective audiences.

Staging remains a central element of intellectual work today. Take, for example, the ritual of inaugural lectures given by newly appointed Chairs at academic institutions. Unlike an ordinary lecture, an inaugural lecture is open to the public, it tends to take place in grand surroundings with local luminaries present, and it is often introduced by senior figures of the university who are appropriately dressed for the occasion - possibly even in gowns and hoods. The whole setting and its pomp convey the significance of the occasion; and indeed the new incumbent is supposed to make his or her intellectual claim, presenting a bold, new outlook, which justifies his or her appointment. The book launch provides another ritual in which the setting plays a significant role. In comparison with inaugural lectures, book launches are ostensibly a more casual affair, but they are nevertheless highly ritualized. The likelihood that the book will be well received is aided 
by its being launched in venues with historic and symbolic significance (a venerable institution like a national academy or a well-established bookshop), and again, especially so if the author is introduced by other respected intellectual figures. Even the eminence of the invitees helps indicate the importance of the occasion, and by association, so too the book. Here, again, the stage helps to consecrate, and a particular script - a sequence of events - is normally expected to be followed.

A stage, as we define it, is a sub-class of a broader device, a frame (e.g. Goffman, 1974), which can itself be described as any setting - physical or conceptual - within which an intellectual intervention takes place and which helps, on the one hand, to impose meanings upon the intervention, and, on the other, to close off certain interpretations. We have already touched on this issue of framing, which is an essential component of intellectual life, and by which intellectual interventions are given shape and direction, helping the audience evaluate and make sense of them. There are plenty of examples in the intellectual and academic realms. In relation to books, their titles, the reputation of the publisher, or their inclusion in a specific series, all help to set the scene. So too do the author biography and cover blurbs. A publisher' s catalogue provides additional framing, signalling significance, niche, and genre to prospective readers. Academic journals likewise offer frames for their articles: the journal' $\mathrm{s}$ reputation, its publisher, editorial board, general intellectual orientation, and now its 'impact factor' . Sequencing might also be crucial as might the length of time or space set aside for a particular intervention: leading articles in special issues, or keynote or plenary lectures suggest relative importance and sacralization.

The above should not give the impression that staging is solely in the hands of the author or that it is carefully manipulated by him or her. Social life is conducted in open systems and therefore, as we mentioned above, systematic contingency comes into play. Sometimes the stage is only partially given - a setting against which the author performs and which, in subsequent readings, happens to attribute particular meaning to his or her writings or speeches. This was to a certain extent the case, for instance, for Rupert Brooke' s war poems. While some of these poems undoubtedly dealt with the battlefield experience, and have a patriotic ring to them, subsequent British audiences have defined Brooke' s legacy virtually exclusively in light of the First World War, focusing on his perceived nationalism and heroism (see, for instance, Rutherford, 1997). The First World War then acted as a stage against which his poetry was read and his figure remembered, attributing intensity and emotive qualities to his work. Brooke became a Romantic hero, with his beauty and that of his poetry contrasted with the horror of conflict. This example demonstrates how the historical context in which intellectuals write often provides a stage which helps imbue their performance with particular meanings, but only insofar as the audience sees the performance as alluding to this context. This is precisely where the broader network of commentators and critics, agents and interpreters play a central role in the making of an intellectual, forming the stage and thereby collectively shaping his or her positioning.

The stage also creates an aura surrounding the actor and his or her intellectual interventions. By aura, we refer to the process by which physical and mental distance is created between the actor and the audience, in some cases, generating audience reverence for the actor. ${ }^{3}$ In the case of a lecture, the distance between the actor and the 
audience is physcial in that the actor and the audience are spatially separated and the former may speak from a pedestal or platform. The distance, however, is also conceptual: the stage suggests that the actor operates in a different, set-apart, more sacred realm in comparison to the audience. Props and devices help establish this sense of otherness: historically, universities expected their lecturers to wear gowns while lecturing. Beyond the academy, the use of media such as radio or television often accentuates this process of distancing, otherworldliness, and potential reverence.

From what we have said so far, it should be clear that the notion of a stage implies the distinction between a backstage and a front stage (Goffman, 1959). We understand this differentiation as important for creating and maintaining a sense of aura, and define backstage not just spatially, but also in temporal terms. A backstage, as we use it here, refers to any time or space within which intellectuals prepare the performance away from the public, or to which they retreat following a public performance. A public intellectual' s appearance on radio and television, for instance, is often preceded by a rehearsal or briefing about the content of the discussion to ensure the programme runs smoothly. A lecture or talk likewise relies on dedicating time to preparation, and publishing normally takes place after the writing of drafts, the incorporation of referees' comments and careful editing work - all these activities count as backstage, during which various people (the writer, referees, editors, and so on) reshape the initial product in accordance with specific norms and expectations, distributing agency and complicating straightforward notions of authorship even before post-structuralist considerations (e.g. Barthes, 1978 [1967]) have been brought into play. More generally, the backstage enables intellectuals to think ahead, or reflect back, consider the possible or actual reactions of an audience to alternative ways of expressing themselves. The backstage, therefore, enables conscious positioning, for thinking through the consequences of particular ways of presenting oneself.

Among the dramaturgical devices that intellectuals employ, rhetoric is particularly important. As Aristotle pointed out, the art of rhetoric relies on three 'means of persuasion' . Persuasion can take place through logical argumentation (logos); through conveying, or relying upon, a desirable character trait, such as trustworthiness, for grounding the authority of one' s message (éthos); and through evoking appropriate emotions in one' s audience (pathos) (Aristotle, 1991). Building on Aristotle' s typology, it is clear that the intellectual sphere brings something unique to all three dimensions.

Logos is meant to be the centrepiece of the intellectual sphere, leading sometimes to meta-theoretical discussions about what counts as superior or fallacious argumentation. Therefore, the intellectual sphere often tends to counterpose rhetorical devices and statements of truth, condemning the former and celebrating the latter, as was famously the case in Plato' s treatment of Gorgias (Plato, 1979). Sometimes, however, metatheoretical arguments are put forward to blur the distinction between the two. Indeed neo-pragmatism and some forms of post-structuralist theory have questioned the possibility of atemporal foundations on which to ground knowledge (e.g. Rorty, 1979, 1982).

In relation to etthos, the intellectual world is also distinctive: in addition to trustworthiness and fair-mindedness, it is important for writers or speakers to exude a sense of gravitas or learnedness. Indeed, in the intellectual realm, these attributes are often interlinked: learnedness is seen as a precondition for trustworthiness. This explains, for instance, introductory blurbs listing one' $s$ achievements in order to assign credibility and thus instil 
trust. In the humanities, the credibility of an intellectual also depends on the form through which their arguments are presented, as well as the references they choose to elaborate their case; they show the author and his or her arguments to be steeped in a broader tradition, allowing the possibility of greater weight and reach.

In relation to pathos, intellectuals also often draw upon powerful metaphors to make an inroad, and the courtroom, for instance, is a deeply ingrained image frequently invoked by intellectuals. ${ }^{4}$ Disputes are then portrayed as analogous to legal cases, with the intellectual assuming the role of the prosecutor and their opponent(s) that of the accused. The audience are then implicitly cast as the presiding judge. Metaphors and analogies of this kind capture attention and provide intensity, creating a sense of drama and suspense. These rhetorical moves, however, do not emerge ex nihilo. They are most likely to be effective when drawing on a set of implicit, shared assumptions, or what Durkheim called 'collective representations' (2001 [1912]), which resonate with the audience, often by mapping onto neat, recognizable dichotomies. Indeed, as in other areas of cultural life (Lévi-Strauss, 1969), intellectuals frequently rely upon shared oppositions, for instance, between modernity and post-modernity, between subject-centred and object-oriented philosophy, between society and the individual, between the state and the market, and so on, in order to successfully engage their audiences.

Rhetorical devices refer to both the past and the future. Again drawing loosely on Aristotle' s treatment of the art of rhetoric, we can distinguish between deliberative, judicial, and epideictic interventions. Deliberative speeches or writings are directed to the future; they aim to encourage certain actions while dissuading others. This is often done by exploring the likely outcomes of various courses of action. Whereas deliberative interventions weigh up possible futures, judicial interventions refer to the past. They are meant to comment positively or negatively on what happened, condemning or praising decisions or actions that have already taken place. In Aristotle' s terminology, epideictic interventions do not necessarily refer to either the past or the future but are meant to praise the moral strength of an individual or condemn the lack of it. In practice, however, the three types of interventions are often interlinked and it is difficult to conceive of epideictic interventions that do not include references to the past or future. Sociological research on the role of intellectuals as carriers of trauma has shown how often the condemnation or praise of individuals ties in with intricate arguments about their alleged responsibility in relation to traumatic events in the past, while those accounts of the past often provide a sense of how to move forward collectively (e.g. Eyerman, 2002, 2011).

In some cases, the general demeanour, appearance, or idiosyncratic behaviour of intellectuals helps situate them within the artistic, intellectual or political arenas. In the minds of many, Immanuel Kant' s rigid lifestyle, divided up into perfectly timed habitual acts, fitted the rigour of his rationalist philosophy, just as Martin Heidegger' s völkisch appearance and mode of living came to be seen as matching the anti-modernist tendencies of his philosophy (and later, his Nazi affiliations too). In a similar fashion, Dylan Thomas' s drunken outbursts and wild lifestyle were subsequently portrayed as a fitting accompaniment to his remarkable talent as a poet - a view popularized by John Malcolm Brinnin’ s (1957) highly influential portrait.

Sometimes, however, these behavioural attributes are more than just complements of intellectual stances or ways in which intellectuals are remembered; they can actually be 
constitutive of the intellectual positioning, and without which the positioning itself would be put at risk. Oscar Wilde' s flamboyant demeanor and camp appearance came to be recognised as part and parcel of his carefree, witty aestheticism; the former instantiated and embodied the latter. Likewise, Sartre and de Beauvoir' s bohemian lifestyle, their refusal to marry and their open relationship came to 'perform' their existentialist philosophy and their drive towards authenticity, just as they enacted their stance of the 'engaged intellectual' through their various political involvements. Similarly, Hirsi Ali' s self-assured and eloquent appearances on Dutch television at the beginning of this century were not only central to her rise as a celebrity figure in the Netherlands, but, as some observers noted, also came to embody and typify her secular, feminist stance (Heynders, 2016: 109 - 12). In the same vein, Steve Biko' s confident demeanour and capacity for highly articulate public speech, did not just fit Black Consciousness as a political philosophy; it was one of the visible ways in which the need for blacks to shed ingrained inferiority complexes was performed.

\section{Sartre as a dramatic public intellectual}

So far we have provided examples covering a broad range of intellectual interventions, we will now focus on the phenomenon of public intellectualism, exemplified through a dramatic performance by perhaps the very archetype of a public intellectual: Jean-Paul Sartre.

In the Anglo-Saxon secondary literature on Sartre, the French philosopher is often remembered for his political interventions in the 1950s and 1960s, for instance, in relation to the Cold War, Algeria, Vietnam, and so on. Until the mid-1940s, however, Sartre' s political awareness was very limited and so was his political involvement. It is around the mid-1940s that Sartre reinvented himself as an 'engaged intellectual' , who saw it as his duty to speak out and commit to political action. Sartre argued that the experience of the Second World War had changed him and he had come to realize how important it was to act politically, using a variety of media - plays, novels, journalism, interviews and lectures - to reposition himself in accordance with his new persona. We shall focus here on one of those public lectures, entitled ' $L$ ' Existentialisme est un humanisme' , which he gave on 29 October 1945 in Paris.

By the time of the lecture, Paris had been liberated for over a year and Germany had surrendered in the Second World War. Sartre had started to establish himself as a major public intellectual, writing for various newspapers and magazines. Within the media, there was a growing interest in the philosophy of existentialism associated with his and others' work. De Beauvoir retrospectively referred to the autumn of 1945 as the 'existentialist offensive' because it was during this period that the French intelligentsia and, to a certain extent, the media in general became captivated by existentialist philosophy. Besides some key novels and plays by both Sartre and de Beauvoir during this period, they also launched the journal Les Temps modernes on 1 October 1945, providing a powerful platform for the exercise of committed intellectualism. Sartre had already become an important figure on the literary and political scene and he had become the target of criticism from both Catholics and members of the Communist Party. The 
former considered his philosophy nihilistic; the latter portrayed it as individualistic and bourgeois (Baert, 2015:91 - 112).

It was against this background that Sartre gave his famous lecture on existentialism. Like theatre, lectures are marked out by the co-presence of speaker and audience and the immediacy of the occasion. Sartre' s lecture took place at the Maison des Centraux in Paris and it was organized by the Club Maintenant, a cultural organization at the time without any distinct political orientation. The organizers were Marc Beigbeder and Jacques Calmy, who would later establish himself as a Sartre expert. The venue was an intimate lecture theatre, providing the ideal stage for Sartre' s carefully orchestrated performance. The lecture was advertised all across Paris and also in many newspapers, including Le Monde, Combat, Le Figaro and Libération. The organizers invited key journalists who subsequently reported on the event. The advertising was so effective that four hundred people turned up; the lecture hall was immensely crowded, surprising even the speaker himself (Cohen-Solal, 2005: 247 - 69).

Sartre' s performance was impeccable. He spoke eloquently and without notes, explained clearly and succinctly what existentialism stood for, and defended it against criticisms from both Catholic and Communist quarters. Sartre had previously used the concept of 'philosophy of existence' , but he now embraced the widely used term 'existentialism' . Keen to show a clean break with the nihilism of his pre-war writings, Sartre also made the link with 'humanism' central to his talk. Existentialism, in this account, was anything but a philosophy of despair, or an individual-centred credo; it was intertwined with the condition of humanity itself. This focus enabled Sartre' s message to resonate well with a primed audience, for whom 'humanism' was already a recognizable and unifying label (Baring, 2010).

During this period, Sartre redefined his philosophy around the notion of responsibility. There is no essence or God, Sartre explained in the lecture, so people are genuinely free, but with this freedom comes enormous responsibility. In so doing, Sartre was clearly tapping into the cultural sensitivities of the time: the notion of responsibility loomed large in the prosecution of wartime collaborators and the French media discussed the notion at length. Sartre' s innovation lay in turning the notion of responsibility into a positive, moral category. For him, individuals had a responsibility to engage with the present, and writers in particular had a duty to involve themselves politically, a theme he developed further in Qu'est-ce que la littérature? (Sartre, 1948), and which he would use as a yardstick to judge and condemn iconic French writers.

If we emphasized the co-presence of speaker and audience, it was, ironically, the subsequent reporting by journalists and other literary figures that helped immortalize the event, as did the subsequent publication of Sartre' s lecture by the publisher Nagel (Sartre, 1946). We have already mentioned that several newspaper journalists were present at the talk; they wrote about the event and commented on Sartre' s eloquence, contributing to the aura surrounding 'the high priest of existentialism' . Other novelists would also help to cement the iconic status of Sartre and his lecture. In Boris Vian' s satirical novel $L^{\prime} E^{\prime}$ cume des jours, for instance, the fictional and thinly veiled characters, Jean-Sol Partre and the Duchesse de Bovouard (de Beauvoir) are major celebrities. When Partre gives a public lecture, it is absolute pandemonium: rioting breaks out just to get into the lecture room; many use forged tickets, while others parachute in or sneak 
in through sewers; and when Partre starts talking, there is fainting all around him, and deafening applause after each pronouncement.

Leaving aside this fictional world, it was first and foremost the short book L'Existentialisme est un humanisme, based on the lecture, that helped canonize the event, and deepen Sartre' s celebrity. For all its faults (in particular, its simplicity and reductionism), this book turned out to be a bestseller, published in numerous languages, becoming, to Sartre' s dismay, the main channel through which a global audience became acquainted with his ideas. The book summed up existentialist dictums with easily digestible catch phrases and slogans such as 'existence precedes essence' or 'people are forced to be free' , and it was peppered with accessible real-life examples (Sartre, 1946).

In sum, Sartre' stalk 'L' Existentialisme est un humanisme' was central to the making of Sartre - to the creation of the Sartre phenomenon. It was a carefully organized public performance and came to be considered as 'the cultural event' of the autumn of 1945 . Interestingly, its power also derived from the myriad recollections of the event, from ecstatic newspaper reporting and overblown literary reviews, to the booklet that was published from it, all in their own way helping to create the Sartre myth.

\section{Concluding comments on recent developments}

To conclude, we would like to discuss some recent developments with regard to the performance of public intellectuals. Some are linked to the emergence of new media, others are tied to an apparent (if not always actual) element of democratization in the relationship between intellectuals and their publics.

The emergence and prevalence of new media have affected the nature of intellectual interventions in various ways, especially within the public realm. First, new technologies have enabled more immediate intervention by public intellectuals than was previously the case. Whereas traditional publishing inevitably involved successive time-lags between writing, publication, diffusion and reception, the new media enable a more instant impact. They allow intellectuals to engage directly with ongoing social and political events. For instance, many academics and public intellectuals provided a running commentary through blogs and social media on the recent EU referendum in the UK, tracking and interpreting the events as they unfolded. Second, there is the potential for democratization of public intellectual life. Due to the accessibility and the interactive nature of the technologies involved, the distinction between intellectuals and their audiences is no longer as clear-cut as it once was. The usual gatekeepers, associated with the more traditional media, do not necessarily hold the same authority, or even exist, in the case of blogs and networking websites (Baert and Booth, 2012). Also, all participants, in principle at least, often have the ability to engage and interact with each other, unsettling old hierarchies and enabling the potential of new forms of dialogue that were previously impossible. Of course, hierarchies persist (in part for many of the reasons we outlined near the beginning of this article), and established intellectuals inevitably find it much easier to find web-space on prominent platforms and command a greater social media following, and hence get their messages across. Nevertheless, the technologies have certainly provided potential openings for non-established figures, savvy to the new mediated world. Third, new technologies reconfigure to a certain extent the ceremonial 
aspects of traditional intellectual interventions. The new social media, for instance, enable a much higher degree of de-contextualization and re-contextualization, whereby articles, videos and posts are re-used on new platforms with new comments, unsettling the careful curation and control over framing that characterized more traditional media. In the case of publishing, intellectual interventions were in the past also occasionally reprinted, allowing for reframing, but new technologies vastly increase the rapidity of this process, as well as its frequency, whilst diminishing the influence that the intellectual holds over such processes. Furthermore, this ongoing reframing and restaging are central to the diffusion of intellectual interventions. In some cases, the re-use of intellectual interventions can involve de-staging, whereby they are stripped to a considerable extent of their ceremonial dimensions. This process can lead to de-sacralization, with intellectuals and their interventions losing certain aspects of their previous aura. It may also, however, and often simultaneously, enhance aura by expanding the reach and celebrity of the author and their contribution.

Besides the new media, there are other new developments in relation to the performance of the public intellectual. With rising educational levels and given the dialogical nature of new technologies, the erstwhile hierarchical relationship between intellectuals and their publics has gradually been unsettled. In the first half of the twentieth century, public intellectuals such as Sartre and Russell tended to act as 'authoritative public intellectuals' , relying on a privileged educational trajectory to speak with great moral authority about a wide range of social and political issues without training or expertise. By the 1960s, with the professionalization of the social sciences, people became less receptive to generalists. 'Expert public intellectuals' came to the surface, drawing on their expertise and methodology in the social sciences to intervene politically (Baert and Shipman, 2012: 190 - 4). Like authoritative public intellectuals, however, they retained a clear distance and hierarchical relationship vis-à-vis their publics, justified through methodologies and expertise. Towards the end of the twentieth century, this hierarchical relationship between the intellectual and the public has been coming unstuck for a variety of reasons. Philosophically, the notion that we can find universal foundations to underscore epistemological, aesthetic or normative claims has been in decline. To the general public, expert knowledge is no longer seen as a neutral device; it is increasingly considered to be political and contestable. With higher levels of education has come an awareness of the fallibility of knowledge claims. One of the upshots of all this has been the potential for a 'democratization' of the public intellectual realm, whereby intellectuals engage with the public on a more equal footing, often drawing on its knowledge, rather than imposing their own (Baert and Shipman, 2012: 194 - 9). Participatory action research (e.g. Freire, 1970) was an earlier expression of these developments, and public sociology (e.g. Burawoy, 2005) offers a more recent example, cooperating with and relying on publics to bring about change.

Some intellectuals still adhere to the picture of the authoritative public intellectual, but they do so differently from the likes of Sartre and Russell because their performances are imbued with irony and a level of self-consciousness that were rare in the early part of the twentieth century. The American pragmatist philosopher Richard Rorty famously pointed out the significance of irony in contemporary liberal thought. According to Rorty, awareness of the contingency of our most firmly held beliefs must ultimately 
lead to an ironic stance (Rorty, 1989). While irony has taken a more central role in public intellectual life, we believe this can be explained more forcefully by the refiguring of the hierarchy implied in the traditional relationship between intellectuals and their publics. Indeed, it is within this context of apparent democratization and to some extent the desacralization of the public intellectual sphere that ironic performances by public intellectuals, such as the Slovenian philosopher Slavoj Z iz ek, become intelligible. At one level, Z iz ek performs as a traditional authoritative public intellectual - he speaks out about a remarkably wide range of issues with a strong moral voice - but on another level his comic showmanship and in particular, alongside intellectuals such as Derrida and Sloterdijk, his frequent tendency to draw attention to the artificiality of his own performances, indicate a performed self-consciousness that was absent in the era of the authoritative intellectual. Brecht famously wrote that the illusion created by theatre must always be partial, so that it can always be recognised as illusion' (1995: 281). A new breed of mediatized public intellectuals appear less concerned with Coleridge' $s$ 'suspension of disbelief' , or Alexander' s (2004) 're-fusion' of the traditional elements of performance, and far more preoccupied instead with Brechtian attacks upon theatrical illusion. The question remains whether this is merely a passing phase of a few exceptional figures, or whether such breaks from traditional dramaturgical rules will become a more permanent feature of public intellectual life.

\section{Declaration of Conflicting Interests}

The authors declared no potential conflicts of interest with respect to the research, authorship, and/ or publication of this article.

\section{Funding}

The authors disclosed receipt of the following financial support for the research, authorship, and/or publication of this article: The research leading to these results has received funding from the European Union Seventh Framework Programme (FP7/2007-2013) under Grant Agreement nº319974 (INTERCO-SSH), as well as funding from the Leverhulme Trust.

\section{Notes}

1. Alexander (2004), for instance, has offered a useful elaboration of what he sees as the six main elements of cultural performance: actors, audience, means of symbolic production, collective representations, mise-en-scène, and power. In a Durkheimian fashion, he argues that under contemporary conditions of de-fusion, in which these elements are no longer tightly bound together or assumed, actors must struggle to 're-fuse' these elements in order for their performances to come off convincingly, and for symbolic extension to be achieved.

2. Indeed, Clifford Geertz described Malinowski' s collected diary entries in precisely these terms: as a 'backstage masterpiece of anthropology' (1988:75).

3. Although we are inspired by Walter Benjamin' s notion of aura, his tends to focus on the art object - not so much on the creator (Benjamin, 2003). In contrast, we tend to use aura in relation to how both the intellectual and his or her products are perceived.

4. The courtroom has also served as a model setting for rhetoric since its earliest elaboration by the Sophists. 


\section{References}

Alexander J C (2004) Cultural pragmatics: Social performance between ritual and strategy.

Sociological Theory 22(4): $527-73$.

Alexander J C (2016) Dramatic intellectuals. International Journal of Politics, Culture, and

Society 29(4): $341-58$.

Aristotle (1991) On Rhetoric: A Theory of Civic Discourse. Oxford: Oxford University Press.

Austin J L (1957) How to Do Things with Words. Cambridge, MA: Harvard University Press.

Baert P (2015) The Existentialist Moment: The Rise of Sartre as a Public Intellectual. Cambridge:

Polity Press.

Baert P and Booth J (2012) Tensions within the public intellectual: Political interventions from

Dreyfus to the new social media. International Journal of Politics, Culture, and Society 25(4):

$111-26$.

Baert P and Shipman A (2012) Transformation of the intellectual. In: Rubio D F and Baert P (eds)

The Politics of Knowledge. London: Routledge, pp. 179 - 204.

Baring E (2010) Humanist pretensions: Catholics, communists, and Sartre' s struggle for existentialism in postwar France. Modern Intellectual History 7(3):581 - 609.

Barthes R (1978 [1967]) The death of the author. In: Barthes R Image, Music, Text (trans. Heath S).

New York: Hill and Wang, pp. 142 - 9.

Benjamin W (2003) The work of art in the age of its technological reproducibility. In: Eiland $\mathrm{H}$ and

Jennings M W (eds) Walter Benjamin: Selected Writings, Vol. 4: 1938-1940. Cambridge, MA:

Harvard University Press, pp. $251-83$.

Berlin I (1967) Four Essays on Liberty. Oxford: Oxford University Press.

Booth J (2015) Publication and intellectual power. Unpublished dissertation, University of Cambridge.

Bourdieu P (1998) State Nobility: Elite Schools in the Field of Power. Stanford, CA: Stanford University Press.

Brecht B (1995) Collected Plays Five. London: Bloomsbury.

Brinnin J (1957) Dylan Thomas in America: An Intimate Journal. London: Viking Press.

Burawoy M (2005) 2004 ASA Presidential address: For public sociology. American Sociological Review 70(1): 4 - 28.

Butler J (1997) Excitable Speech: A Politics of the Performative, New York: Routledge.

Charles R (2015) Birth of the Intellectuals, 1880-1900. Cambridge: Polity Press.

Cohen-Solal A (2005) Jean-Paul Sartre: A Life. London: The New Press.

Collini S (2006) Absent Minds: Intellectuals in Britain. Oxford: Oxford University Press.

Collins L (ed.) (1976) The Use of Models in the Social Sciences. London: Tavistock.

Collins R (2000) The Sociology of Philosophies: A Global Theory of Intellectual Change.

Cambridge, MA: Harvard University Press.

Craveri B (2007) The Age of Conversation. New York: New York Review of Books.

Durkheim E (1997 [1893]) The Division of Labor in Society. New York: Free Press.

Durkheim E (2001 [1912]) The Elementary Forms of Religious Life. Oxford: Oxford University Press.

Eyerman R (2002) Cultural Trauma: Slavery and the Making of African American Identity.

Cambridge: Cambridge University Press.

Eyerman R (2011) Intellectuals and cultural trauma. European Journal of Social Theory 14(4): $453-67$. 
Freeman D (1983) Margaret Mead in Samoa: The Making and Unmaking of an Anthropological

Myth. Cambridge, MA: Harvard University Press.

Freire P (1970) Pedagogy of the Oppressed. New York: Seabury Press.

Geertz C (1980) Negara: The Theatre State in Nineteenth-Century Bali. Princeton, NJ: Princeton University Press.

Geertz C (1987) Works and Lives: The Anthropologist as Author. Stanford, CA: Stanford University Press.

Goffman E (1959) The Presentation of Self in Everyday Life. London: Random House.

Goffman E (1974) Frame Analysis: An Essay on the Organization of Experience. Cambridge,

MA: Harvard University Press.

Gramsci A (1971 [1929 - 1935]) Selections from the Prison Notebooks. London: Lawrence \& Wishart. Granovetter M (1973) The strength of weak ties. American Journal of Sociology 78(6): 1360 - 80. Gross N (2009) Richard Rorty: The Making of an American Philosopher. Chicago: University of Chicago Press.

Habermas J (1992) The Structural Transformation of the Public Sphere: Inquiry into a Category of Bourgeois Society. Cambridge: Polity Press.

Hayek F A von (2001 [1944]) The Road to Serfdom. London: Routledge.

Heynders O (2016) Writers as Public Intellectuals: Literature, Celebrity, Democracy. London: Palgrave.

Latour B (2001) Gabriel Tarde and the end of the social. In: Joyce P (ed.) The Social in Question:

New Bearings in History and the Social Sciences. London: Routledge, pp. 117 - 32.

Lefebvre H (1946) L'Existentialisme. Paris: Éditions du Sagittaire.

Lévi-Strauss C (1969) The Raw and the Cooked: Introduction to a Science of Mythology, Vol. I.

New York: Harper \& Row.

Malinowski B (1967) A Diary in the Strict Sense of the Term. Stanford, CA: Stanford University Press.

Mills C W (1940) Situated actions and vocabularies of motives. American Sociological Review 5(6): $904-13$.

Morgan M and Baert P (2015) Conflict in the Academy: A Case-Study in the Sociology of Intellectuals. London: Palgrave.

Noble D L (2006) Beyond the Promised Land: The Movement and the Myth. Toronto: Between the Lines Press.

Plato (1979) Gorgias. Oxford: Oxford University Press.

Popper K (1971 [1945a]) The Open Society and its Enemies, Vol. 2: Hegel, Marx, and the Aftermath. Princeton, NJ: Princeton University Press,

Popper K (2002 [1957]) The Poverty of Historicism. London: Routledge.

Popper K (2013 [1945b]) The Open Society and its Enemies, Vol. 1: The Spell of Plato. Princeton,

NJ: Princeton University Press.

Posner R (2009) A Failure of Capitalism: The Crisis of '08 and the Descent into Depression.

Cambridge, MA: Harvard University Press.

Rorty R (1979) Philosophy and the Mirror of Nature. Princeton, NJ: Princeton University Press. Rorty R (1982) Consequences of Pragmatism. Minneapolis: University of Minnesota Press. Rorty R (1989) Contingency, Irony, and Solidarity. Cambridge: Cambridge University Press. Rutherford J (1997) Forever England: Reflections of Race, Masculinity and Europe. London: Lawrence \& Wishart. 
Sartre J-P (1946) L'Existentialisme est un humanisme. Paris: Nagel.

Sartre J-P (1948) Qu'est-ce que la littérature? Paris: Gallimard.

Schechner R (1977) Ritual, Play, and Social Drama. New York: Seabury Press.

Sennett R (1977) The Fall of Public Man. London: Penguin.

Turner V (1968) Schism and Continuity in an African Society: A Study of Ndembu Village Life.

Manchester: Manchester University Press.

Turner V (1974) Dramas, Fields, and Metaphors: Symbolic Action in Human Society. Ithaca, NY:

Cornell University Press.

Weber M (1978) Economy and Society. Berkeley: University of California Press.

Weber M (1993) Sociology of Religion. New York: Beacon Press.

\section{Author biographies}

Patrick Baert is Professor of Social Theory at the University of Cambridge and a Fellow of Selwyn College, Cambridge. Among his recent publications are The Existentialist Moment: The Rise of Sartre as a Public Intellectual (Polity Press, 2015) and (with Marcus Morgan) Conflict in the Academy: A Study in the Sociology of Intellectuals (Palgrave, 2015).

Marcus Morgan is a Leverhulme Early Career Fellow in the Department of Sociology at the University of Cambridge, and a Fellow of Murray Edwards College, Cambridge. His recent publications include Pragmatic Humanism: On the Nature and Value of Sociological Knowledge (Routledge, 2016) and (with Patrick Baert) Conflict in the Academy: A Study in the Sociology of Intellectuals (Palgrave, 2015). 